\title{
Advances in Toxoplasma gondii Vaccines: Current Strategies and Challenges for Vaccine Development
}

\author{
Ki-Back Chu ${ }^{1}$ and Fu-Shi Quan ${ }^{2,3, * \text { (D) }}$ \\ 1 Department of Biomedical Science, Graduate School, Kyung Hee University, Seoul 02447, Korea; \\ kbchu@khu.ac.kr \\ 2 Medical Research Center for Bioreaction to Reactive Oxygen Species and Biomedical Science Institute, \\ School of Medicine, Graduate School, Kyung Hee University, Seoul 02447, Korea \\ 3 Department of Medical Zoology, School of Medicine, Kyung Hee University, Seoul 02447, Korea \\ * Correspondence: fsquan@khu.ac.kr
}

Citation: Chu, K.-B.; Quan, F.-S. Advances in Toxoplasma gondii Vaccines: Current Strategies and Challenges for Vaccine Development. Vaccines 2021, 9, 413. https:/ / doi.org/10.3390/vaccines 9050413

Academic Editor: Ralph A. Tripp

Received: 5 April 2021

Accepted: 20 April 2021

Published: 21 April 2021

Publisher's Note: MDPI stays neutral with regard to jurisdictional claims in published maps and institutional affiliations.

Copyright: (C) 2021 by the authors. Licensee MDPI, Basel, Switzerland. This article is an open access article distributed under the terms and conditions of the Creative Commons Attribution (CC BY) license (https:// creativecommons.org/licenses/by/ $4.0 /)$.

\begin{abstract}
Toxoplasmosis, caused by the apicomplexan parasite Toxoplasma gondii, is one of the most damaging parasite-borne zoonotic diseases of global importance. While approximately one-third of the entire world's population is estimated to be infected with T. gondii, an effective vaccine for human use remains unavailable. Global efforts in pursuit of developing a T. gondii vaccine have been ongoing for decades, and novel innovative approaches have been introduced to aid this process. A wide array of vaccination strategies have been conducted to date including, but not limited to, nucleic acids, protein subunits, attenuated vaccines, and nanoparticles, which have been assessed in rodents with promising results. Yet, translation of these in vivo results into clinical studies remains a major obstacle that needs to be overcome. In this review, we will aim to summarize the current advances in T. gondii vaccine strategies and address the challenges hindering vaccine development.
\end{abstract}

Keywords: Toxoplasma gondii; vaccine; immune response; protection

\section{Introduction}

Toxoplasma gondii has become a pathogen of global importance with 2 billion individuals being estimated to be infected with this Apicomplexan parasite [1]. In humans, the transmission of this parasite through the consumption of undercooked or contaminated food products can have severe consequences depending on the host's immune system status. In immunocompetent healthy individuals, T. gondii infection tends to result in mild unspecific symptoms or asymptomatic as a whole, whereas their infection in immunocompromised or pregnant individuals incurs congenital toxoplasmosis which leads to premature abortion and ocular toxoplasmosis [2]. Currently, the gold standard therapeutic option for $T$. gondii infection involves the use of pyrimethamine and sulfadiazine [3]. However, there is a worrying trend of increased drug resistance in T. gondii which may exacerbate the disease severity and result in treatment failure [2]. Moreover, while drug treatment has been proven to be effective against $T$. gondii tachyzoites, they were virtually ineffective against tissue-encysted bradyzoites and latent stages of T. gondii [4]. In 2015, the financial scandal involving pyrimethamine caused a massive uproar. With the cost of pyrimethamine undergoing a 5000\% increase overnight from $\$ 13.50$ to $\$ 750$ per pill, alternative options to deal with toxoplasmosis have become a necessity since this generic drug has become more or less unaffordable [5]. Vaccination is widely considered as the most cost-effective method of disease prevention and has a tremendous influence on a socioeconomic level [6]. Given these circumstances, an efficacious vaccine that prevents toxoplasmosis would be a major medical advancement and greatly benefit the globe.

Toxovax, a live-attenuated vaccine based on the tachyzoites of T. gondii S48 strain, is currently the only commercially available toxoplasmosis vaccine [7]. Unfortunately, there are several limitations to this vaccine. First, the vaccine usage and administration are 
strictly limited to veterinary purposes and have an extremely short shelf life of 10 days [7]. Secondly, because the vaccine is based on a live-attenuated pathogen, its administration in humans is impossible due to ethical reasons and safety concerns. In particular, attenuated vaccines are capable of reverting to its virulent wild-type form and cause diseases that it was meant to prevent, hence completely defeating the purpose of the vaccine. As such, developing an effective toxoplasmosis vaccine suitable for humans is highly desired. In this review, we will discuss the recent progress in the development of toxoplasmosis vaccines using DNA, protein, nanoparticles, live-attenuated, and carbohydrate vaccine platforms and address their accomplishments in animal models as well as some of their outlying concerns.

\section{Vaccine Platforms against T. gondii}

\subsection{DNA and Vectored Vaccines}

DNA vaccines are perhaps one of the most efficient vaccine platforms reported to date. Some of the key features that continue to fuel their research stems from their low production cost, ease of production, capability for inducing both humoral and cellular immune response, etc. [8]. To date, multitudes of $T$. gondii DNA vaccine studies have been conducted. Nevertheless, the results have been more or less conflicting. Specifically, while majority of the vaccines triggered antibody responses and production of the cytokine IFN- $\gamma$, the degree to which vaccines protected mice varied as indicated by survival and brain cyst counts. The vast majority of the T. gondii DNA vaccine studies were conducted using several well-characterized $T$. gondii virulence factors, such as the rhoptry proteins (ROP), dense granule proteins (GRA), microneme proteins (MIC), and the surface antigens (SAG). Immunizing the mice with vaccines expressing ROP1 induced a potent Th1 immune response that provided partial protection upon a lethal challenge with T. gondii $\mathrm{RH}$ strain [9]. ROP13 DNA vaccine immunization enhanced IL-17 and IL-22 mRNA expressions and limited the circulating parasite load following an RH challenge in the blood of mice [10]. Interestingly, the level of parasite inhibition demonstrated by this vaccine was similar to those induced by T. gondii lysate antigen (TLA) immunization [10]. Immunization with $T$. gondii ROP16 DNA vaccine expressed using the canine adenovirus significantly bolstered the production of cytokines IFN- $\gamma$, IL2-, and IL-4, and partially protected mice against RH challenge infection [11]. Similarly, subcutaneous and intranasal ROP18 vaccine administration induced a mixed Th1/Th2 systemic immune response as indicated by the production of IFN- $\gamma$, IL2-, and IL-5 cytokines in mice [12]. Nevertheless, brain cyst reduction was only observed when this vaccine was administered through the intranasal route upon a challenge infection with the Type II $76 \mathrm{~K}$ strain, and neither vaccination route induced significant enhancements to $\mathrm{CD} 8^{+} \mathrm{T}$ cell proliferation [12]. DNA vaccine encoding the ROP54 reduced the brain cysts by $35.9 \%$ and also significantly prolonged the survival of immunized mice following a PRU and RH strain challenge, respectively [13]. Immune protection induced by the ROP21 vaccine was similar to previous studies, characterized by high antibody titers and IFN- $\gamma$ levels and partial protection against both RH and PRU strains [14].

Studies using GRA2 and GRA5 DNA vaccines also revealed that both of these vaccines elicited potent Th1 cytokine responses while marginally prolonging survival post-challenge with the RH strain [15]. While significantly enhanced IL-4 and IL-10 cytokine productions were observed, their quantities were considered relatively low in comparison to IL-2 and IFN- $\gamma$ levels [15]. GRA16 DNA vaccine induced a drastic increase in IL-2, IFN- $\gamma$, and IL-10 cytokine levels while a marginal increase in IL-4 was observed. Although their enhancements did not contribute to prolonging the survival of immunized mice, noticeable reductions in brain cyst counts were observed [16]. GRA24 DNA vaccine immunization, characterized by a marked increase in cytokine productions, $\mathrm{T}$ cell proliferation, and antibody responses drastically prolonged the survival of immunized mice following a challenge infection with a lethal dose of RH strain [17]. Several well-characterized genes 
have been widely incorporated as vaccine components in multiple vaccine platforms as illustrated in Figure 1.

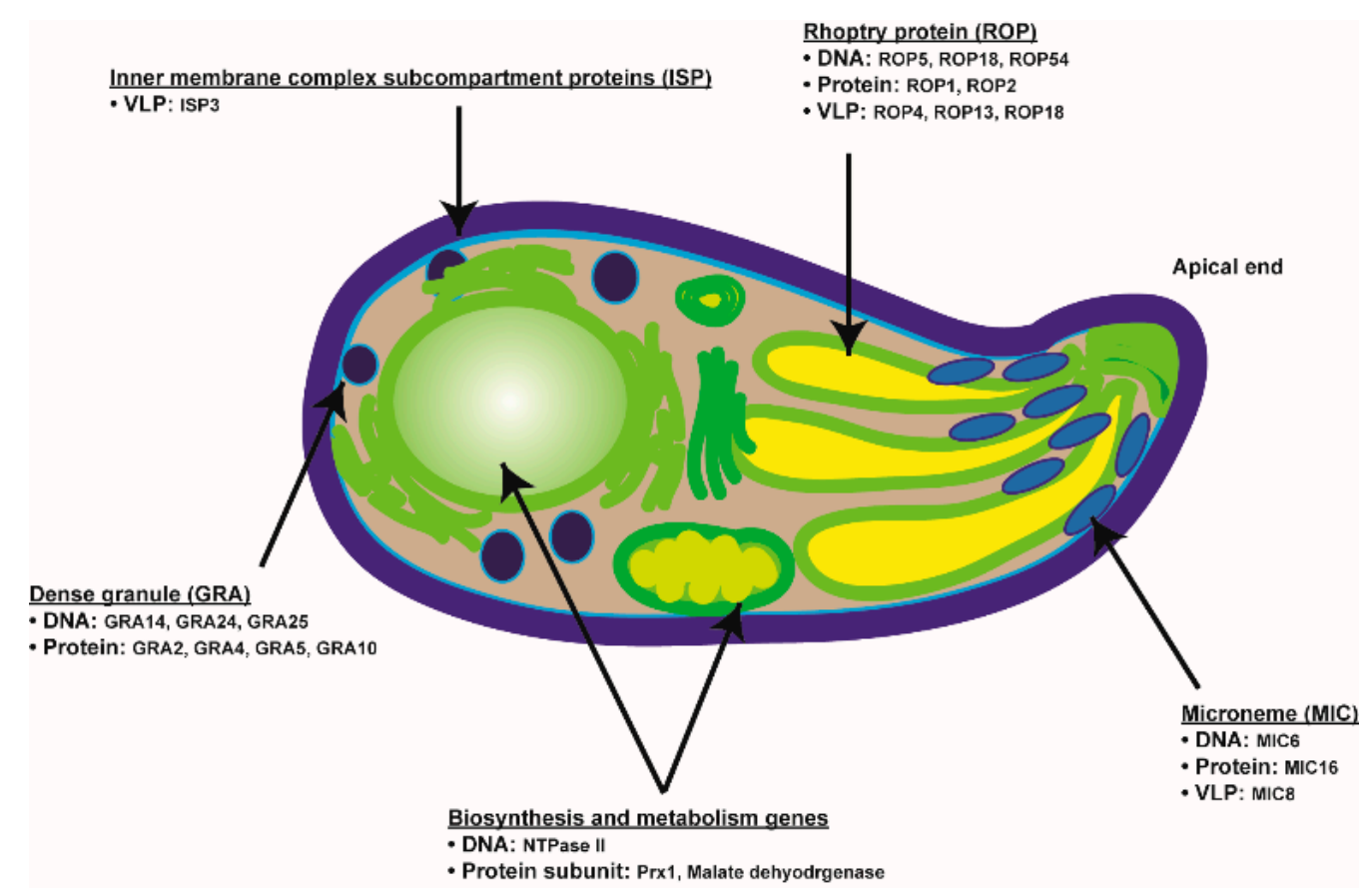

Figure 1. Brief diagram depicting T. gondii target antigens and the vaccine platforms used to assess their efficacies in animal models.

Apart from these well-characterized antigens, several other antigens were investigated as a potential vaccine candidate antigen. A vaccination study using the plasmid DNA vaccine expressing the heat shock protein (Hsp) 40 reported that its immunization partially reduced the brain cyst burden and prolonged the survival of mice challenged with PRU and $\mathrm{RH}$ strains, respectively, despite failing to induce parasite-specific antibody responses and Th1/Th2-associated cytokines [18]. DNA vaccine encoding the Myc regulation 1 (MYR1) induced both humoral and cellular immune responses contributing to prolonged survival of immunized mice post-challenge with RH strain [19]. Similar to vaccines designed using the ROP or the GRA family antigens, mice immunized with the MYR1 DNA vaccine demonstrated elevated antibody responses, $\mathrm{CD} 4^{+}$and $\mathrm{CD} 8^{+} \mathrm{T}$ cells, and several cytokines associated with Th1 and Th2 immunity [19]. Vaccines constructed using the T. gondii calcium-dependent protein kinases (CDPK) partially protected mice against an RH strain challenge infection. Both of the vaccines constructed using CDPK1 [20] and CDPK2 [21] conferred a similar degree of protection, as indicated by prolonged survival and high levels of IFN- $\gamma$, IL-12(p70), and IL-10 production. Doc2, a gene involved in calcium signaling, has been investigated as a vaccine target. DNA vaccine expressing this gene significantly prolonged the survival in Kunming mice following an RH challenge infection and drastically lessened the brain cyst burden post-challenge with PRU strain [22].

Adjuvanting the DNA vaccines was found to enhance the vaccine-induced protective immune responses. The GRA14 DNA vaccine, although it successfully induced antibody responses and enabled lymphocyte proliferation as well as inducing Th1 cytokines, merely prolonged the survival of mice by a few days following a lethal challenge with $\mathrm{RH}$ strain [23]. Supplementing this GRA14 DNA vaccine with a calcium phosphate nanoparticle adjuvant increased the $T$. gondii-specific IgG1 and IgG2a antibody responses as well as lymphocyte proliferation, albeit failing to result in enhanced survival [24]. Vaccines expressing the B and T cell epitopes of ROP29 adjuvanted with resiquimod (R848), an agonist of Toll-like receptor (TLR) 7/8, enhanced the antibody responses and Th1 cytokine production as well as further reducing the brain cyst burden compared to the unadju- 
vanted control group post-challenge with PRU strain [25]. A multi-epitope ROP8 vaccine co-delivered with the genetic adjuvant IL-12 promoted antibody production and Th1 immune responses, with a marginal increase in survival [26]. Compared to single antigen vaccines or unadjuvanted multi-antigen DNA vaccines, adjuvanted multi-antigen vaccines encompassing SAG1 and GRA7 conferred the highest degree of protection against a lethal RH challenge [27]. An ROP5 and ROP18 DNA cocktail vaccine combined with the molecular adjuvant IL-33 significantly enhanced the protective efficacy of the vaccines against challenge infections with RH and PRU strains, indicated by the prolonged survival time of 30 days and minimal brain cysts, respectively [28]. A DNA vaccine encompassing SAG1 and ROP2 adjuvanted with the hepatitis B virus (HBV) antigen evoked an immune response contributing to the survival of immunized mice, while the unadjuvanted control groups perished by 9 days post-infection (dpi) [29]. Interestingly, unadjuvanted vaccines expressing ROP13 and GRA14 conferred better protection against T. gondii infection in the absence of adjuvants [30]. While alum-adjuvanted ROP13+GRA14 vaccines contributed to higher Th2 response induction in mice, a marginally extended survival rate was observed from mice immunized with unadjuvanted ROP13+GRA14 vaccines [30].

DNA vaccines expressing multiple antigens generally conferred better protection against $T$. gondii than single antigen vaccines (Table 1 ). A cocktail DNA vaccine comprising T. gondii profilin, ROP16, ROP18, microneme protein (MIC) 6, and CDPK3 conferred substantial protection against the PRU strain, as indicated by heightened Th1-associated cytokines and diminished brain cysts [31]. Notably, marginally higher brain cyst reduction was detected from mice immunized with the vaccine expressing all five aforementioned antigens than those expressing only four out of the five antigens [31]. Consistent with these findings, a multi-antigenic DNA vaccine expressing GRA24, GRA25, and MIC6 induced the highest level of protection compared to the single antigen or GRA24 and GRA25 combined vaccines [32]. A single dose of hexaplex modified dendrimer nanoparticle vaccine carrying replicons encoding GRA6, ROP2A, ROP18, SAG1, SAG2A, and AMA1 successfully protected mice against a lethal challenge infection with PRU $\Delta h x g p r t$ strain [33]. Multi-epitope DNA vaccine formulated by fusing the surface antigen 1 (SAG1) with ROP2 and delivered using the hepatitis B virus core antigen significantly enhanced antibody production and splenic IFN- $\gamma$ production in mice [34]. Striking differences in protection against low and high $\mathrm{RH}$ infective doses were observed from mice immunized with recombinant adenovirus vaccine expressing MIC3, ROP9, and SAG2 antigens [35]. Contrary to the findings above, the number of antigens displayed by a vaccine did not necessarily correlate with the highest level of protection. Evidently, the highest survival rate was observed from mice immunized with ROP9 and MIC3-expressing vaccines, which even surpassed the survival rate demonstrated by the SAG2-ROP9-MIC3 immunization group [35]. Regardless of these discrepancies, the consensus appears to be that superior protective efficacy can be observed from multi-antigenic vaccines.

The method of vaccine delivery and vaccination routes also impacted the efficacy of DNA vaccines. Immunizing mice with a suicidal nucleic acid vaccine expressing the T. gondii nucleoside triphosphate hydrolase II (NTPase II) resulted in a Th1 predominant immune response which partially protected against RH $\Delta K u 80$ and PRU strains [36]. When encapsulated in lipid nanoparticles, NTPase II vaccine efficacy was greatly enhanced against both RH and PRU strains. Notably, $20 \%$ of the mice immunized with nanoparticleencapsulated vaccines survived post-challenge with RH strain whereas all of the mice immunized with a non-encapsulated NTPase II vaccine perished 15 dpi [37]. Similarly, mice immunized with the T. gondii profilin-expressing DNA vaccine delivered using lipid nanoparticles were protected from a challenge infection with PLK strain [38]. Different routes of vaccine administration induced different levels of protection. Upon immunizing mice with recombinant adenovirus vaccines expressing ubiquitin-conjugated multi-stage antigen segments, it was demonstrated that mucosal immunization routes were far more effective at conferring protection than systemic immunization routes [39]. 
Table 1. An overview of the T. gondii DNA vaccines and their efficacies. Only the studies that assessed all four of the parameters listed below were selected and referenced in the table. Survival refers to the total duration of survival for immunized mice. +, weak; ++ intermediate; +++ strong.

\begin{tabular}{|c|c|c|c|c|c|c|}
\hline Vaccine Platform & $\begin{array}{c}\text { Animal } \\
\text { Model }\end{array}$ & $\begin{array}{l}\text { Antibody } \\
\text { Response }\end{array}$ & $\begin{array}{l}\text { Cellular } \\
\text { Immune } \\
\text { Response }\end{array}$ & $\begin{array}{c}\text { Parasite } \\
\text { Burden } \\
\text { Reduction }\end{array}$ & Survival & Reference \\
\hline \multicolumn{7}{|l|}{ DNA vaccine } \\
\hline ROP54 & & + & ++ & + & RH: 15 days & [13] \\
\hline GRA16 & & + & ++ & + & RH: 10 days & [16] \\
\hline HSP40 & & + & + & + & RH: 10 days & [18] \\
\hline DOC2C & Mouse & + & ++ & + & $\mathrm{RH}:>15$ days & [22] \\
\hline GRA14 & & ++ & + & ++ & RH: $>8$ days & {$[23,24]$} \\
\hline ROP5+ROP18 & & +++ & ++ & ++ & $\mathrm{RH}:>28$ days & [28] \\
\hline GRA24+GRA25+MIC6 & & ++ & +++ & ++ & $\mathrm{RH}:>20$ days & [32] \\
\hline NTPase II & & + & ++ & + & $\begin{array}{c}\text { RH: } 18 \text { days, } \\
20 \%\end{array}$ & {$[36,37]$} \\
\hline
\end{tabular}

Vaccination regimen also had a profound effect on regulating parasite burden in mice. Different immunization regimens have been an effective method of inducing protection in animal models. Priming mice with a multi-epitope vaccine adjuvanted with glucopyranosyl lipid adjuvant-stable emulsion (GLA-SE), followed with multi-epitope polypeptide protein vaccine boost enhanced IFN- $\gamma$-producing memory $\mathrm{CD} 8^{+} \mathrm{T}$ cell population and limited the cyst load following an ME49 strain challenge infection [40]. The protective efficacy of a T. gondii DNA vaccine expressing the secreted protein with an altered thrombospondin repeat (SPATR) induced a mixed Th1/Th2 response and significantly prolonged the survival of mice post-challenge with T. gondii RH strain [41]. Mice immunized with the SAG4 DNA vaccine along with its $B / T$ cell epitope polypeptides elicited antibody responses and Th1dominant immune responses, in addition to prolonging survival and reducing brain cysts against lethal RH and PRU strain challenges, respectively [42]. GRA14 immunization via DNA prime and protein boost coated with calcium phosphate further prolonged the survival of mice infected with $\mathrm{RH}$ strain than prime-boost immunization with DNA vaccine only [43].

\subsection{Protein and Recombinant Subunit Vaccines}

Protein vaccines incorporate a highly purified antigen as the vaccine component. Due to this, protein and subunit vaccines are extremely safe and chances of side effects occurring in recipients are low. However, as with DNA vaccines, their immunogenicity pales in comparison to live-attenuated vaccines and for this platform to be used, a specific antigen involved in disease pathogenesis must be identified [44]. Similar to the T. gondii DNA vaccines, a wide array of antigens have been explored for potential vaccine candidacy ranging from the aforementioned well-characterized $T$. gondii genes to crude extract lysate antigens, as well as other proteins involved in biosynthetic pathways (Table 2). Irradiated T. gondii tachyzoite antigen extracts were found to be capable of priming the immune system, with potent humoral and cellular immunity being induced to confer protection against RH and ME49 strains in mice [45]. Irradiating the T. gondii soluble antigens with a high radiation dose conferred a similar level of protection to those induced by irradiated $\mathrm{RH}$ tachyzoites [46]. While the effects of radiation from both were more or less similar, as indicated by identical levels of peripheral B cell inductions in blood and survival rates, an irradiated soluble antigen induced greater percentage of $\mathrm{CD} 4^{+} \mathrm{T}$ cells whereas irradiated $\mathrm{RH}$ tachyzoites had a greater influence on $\mathrm{CD}^{+} \mathrm{T}$ cell induction [46]. The efficacy of lysate antigen-based vaccines was further assessed in swine. Consistent with the findings from mice, vaccines designed using the T. gondii lysate antigens adjuvanted with QuilA reduced the parasite burden in the muscle tissues of swine [47]. 
Table 2. An overview of the T. gondii protein and subunit vaccines and their efficacies. Only the studies that assessed all four of the parameters listed below were selected and referenced in the table. Survival refers to the total duration of survival for immunized mice. +, weak; ++ intermediate; +++ strong.

\begin{tabular}{|c|c|c|c|c|c|c|}
\hline Vaccine Platform & Animal Model & $\begin{array}{l}\text { Antibody } \\
\text { Response }\end{array}$ & $\begin{array}{l}\text { Cellular } \\
\text { Immune } \\
\text { Response }\end{array}$ & $\begin{array}{c}\text { Parasite } \\
\text { Burden } \\
\text { Reduction }\end{array}$ & Survival & Reference \\
\hline \multicolumn{7}{|l|}{ Protein subunit } \\
\hline $\begin{array}{l}\text { Multiantigenic } \\
\text { epitopes }\end{array}$ & & ++ & + & + & RH: 16 days & [48] \\
\hline Multi-epitope & & ++ & + & ++ & RH: 21 days & [49] \\
\hline Prx1 & & +++ & + & + & PLK: >60\% & [50] \\
\hline MIF & Mouse & +++ & + & ++ & $\mathrm{RH}:>30 \%$ & [51] \\
\hline $\begin{array}{c}\text { Malate } \\
\text { dehydrogenase }\end{array}$ & & ++ & ++ & ++ & RH: $50 \%$ & [52] \\
\hline Actin depolF & & ++ & + & + & RH: $40 \%$ & [53] \\
\hline CDPK3 & & +++ & + & + & RH: 16 days & [54] \\
\hline $\begin{array}{c}\text { Tyrosine } \\
\text { hydroxylase }\end{array}$ & & +++ & ++ & + & $\begin{array}{l}\text { RH: } 18 \text { days; } \\
\text { PRU: } 50 \%\end{array}$ & [55] \\
\hline ERK7 & & + & ++ & + & $\begin{array}{l}\text { RH: } 19 \text { days; } \\
\text { PRU: } 50 \%\end{array}$ & [56] \\
\hline
\end{tabular}

As demonstrated when using DNA vaccines, antigens delivered using nanoparticles have been reported to be promising. When T. gondii extract antigens were delivered using porous nanoparticles, its immunization in mice elicited a potent Th1/Th17 cellular immunity and ensured that all of the immunized mice survived the lethal challenge with T. gondii $76 \mathrm{~K}$ strain with drastically reduced brain cyst counts [57]. Nanospheres loaded with $T$. gondii histone $\mathrm{H} 2 \mathrm{~A} 1$ protected mice against the virulent $\mathrm{RH}$ strain by prolonging survival and enhanced the production of Th1 cytokines in a dose-dependent manner [58]. When vaccines with multiple antigen components were delivered using nanoparticles, significant enhancements to vaccine efficacies were observed. A single dose of chimeric protein vaccine comprising SAG1 and SAG2 encapsulated in poly(lactideco-glycolide (PLGA) conferred protection against a lethal challenge infection with RH tachyzoites in mice [59]. Similarly, the T. gondii vaccine expressing the T and B cell epitopes of AMA1, GRA4, ROP2, and SAG1 delivered in PLGA nanoparticles invoked potent Th1 responses in mice and conferred better protection than the identical vaccine adjuvanted with alum [48]. GRA10 epitope delivery in chitosan-based nanoparticles induced Th1dominant immune responses in mice and conferred partial protection against both acute and chronic toxoplasmosis [49].

Interesting results have been reported from subunit vaccines expressing stress responseassociated proteins. A peroxiredoxin 1-based T. gondii vaccine triggered the production of IL-12p40 and IL-6 cytokines in murine peritoneal macrophages and promoted survival of mice post-challenge with the PLK strain while severely restricting parasite replication [50]. Immunizing mice with a T. gondii Hsp70 subunit vaccine combined with Alum neither altered the cytokine profiles nor exerted any functional effect on the parasite by itself. Yet, the vaccine still managed to confer partial protection in mice challenged with the ME49 strain via oxidative stress regulation involving iNOS expression [60]. T. gondii vaccines expressing the macrophage migration inhibitory factor (MIF) significantly protected immunized mice against acute and chronic toxoplasmosis upon a challenge infection with $\mathrm{RH}$ tachyzoites and PRU cysts [51].

Biosynthetic enzymes and other proteins involved in several signaling pathways have also been used as target antigens for the $T$. gondii vaccine, but their results varied widely. Partial protection against RH strains was observed from mice immunized with the parasite's malate dehydrogenase [52] or T. gondii actin depolymerizing factor [53], as both of these studies ensured the survival of approximately $40 \%$ of the immunized along with significant parasite burden reductions in the liver and the brain. The recombinant $T$. gondii CDPK3 vaccine elicited partial protection against RH tachyzoite and a PRU challenge 
infection in mice, characterized by high antibody titers and a Th1-dominant immune response [54]. Protective efficacy of tyrosine hydroxylase-based vaccines has been explored, but the protection induced was mild in spite of the humoral and cellular immunity induced through immunization [55]. In one study, T. gondii vaccines expressing extracellular signalrelated kinases were used to immunize the mice on a weekly basis for 5 consecutive weeks. This Freund's adjuvant-supplemented vaccine imparted partial protection against both GT1 and PRU challenge infections [56].

Protective efficacy of multi-antigenic subunit vaccines has also been investigated. Subunit vaccines comprising of GRA2 and GRA5 strongly enhanced Th1-associated cytokine response and prolonged survival against an RH tachyzoite challenge infection in mice [61]. Synthetic B and T cell epitopes of GRA2 can partially protect immunized mice against an ME49 challenge infection [62]. Chimeric protein vaccine comprising fragments of AMA1 fused to SAG1, GRA2, and ROP1 were assessed, with all of the generated chimeric vaccines conferring decent levels of humoral and cellular immune responses [63]. Similarly, protein vaccines based on B and Th cell epitopes of T. gondii aspartic protease 3 promoted the production of Th1 cytokines and prolonged survival for as long as 18 days after a challenge infection with the virulent RH strain [64]. MIC16 expressed on the surface of the yeast Saccharomyces cerovisiae, elicited both humoral and cellular immune responses after 3 immunizations which protected mice against a lethal dose of RH tachyzoites [65]. SAG1 peptide adjuvanted with the plant Nicotiana benthamiana Hsp90 significantly reduced the brain cyst load and conferred partial protection in immunized mice challenged with ME49 strain [66].

Dendritic cells are of keen interest for improving vaccine efficacy as their targeting has been demonstrated to be an effective method against chronic toxoplasmosis. SAG1 targeting of DEC205 endocytic receptor on dendritic cells via single-chain fragment variable antibody enhanced both cellular and humoral immune responses in mice, which contributed to strongly inhibiting brain cyst formation [67]. Effective bone marrow dendritic cell activation was observed from multi-antigen protein vaccines comprising GRA7 and T. gondii profilin compared to either antigen alone, and this enabled effective induction of humoral and cellular immunity [68].

\subsection{Nanoparticles, Virus-Like Particle Vaccines}

Self-assembling nanoparticle vaccines have recently emerged as a novel vaccine platform for T. gondii vaccine design. Generally, nanoparticles have been widely utilized as vaccine carriers. By incorporating this strategy, antigens that would otherwise undergo proteolytic degradation are protected, thus ensuring their successful uptake by antigenpresenting cells for immune response induction [69]. At present, only a few studies have explored their potential as T. gondii vaccines. Though limited in number, the results seem to point towards the fact that these vaccines are highly efficacious. A multi-epitope nanoparticle vaccine adjuvanted with the GLA-SE stimulated IFN- $\gamma$ secretion and conferred robust protection against a Type II T. gondii ME49 challenge infection in HLA transgenic mice [70]. Similarly, a chimeric polypeptide vaccine expressing the CD4 T cell, CD8 T cell, and B cell epitopes emulsified in GLA-SE conferred protection against several different HLA transgenic mice [71]. Intranasal administration of maltodextrin-based nanoparticle vaccines formulated with total $T$. gondii antigen extracts was highly protective against chronic and congenital toxoplasmosis in mice [72]. The same vaccine was later assessed in sheep and was also confirmed to be effective at preventing latent and congenital toxoplasmosis in ewes [73].

Previous studies have investigated the anti-parasitic effect of metallic nanoparticles. Nanoparticles based on inorganic metals such as gold, silver, and platinum were reported to demonstrate an anti-T. gondii effect whose mechanism of action appeared to involve altering the redox potential of the parasite [74] and several metallic alloys were also confirmed to restrict the growth of T. gondii in vitro [75]. Administering biogenic silver nanoparticles reduced the proliferation of T. gondii by recruiting inflammatory mediators in trophoblast cell 
lines, whereas the parasitic reductions occurred independently of inflammatory mediators in chorionic villi [76].

Virus-like particles (VLPs) are another novel approach to vaccine development. VLPbased vaccines have underwent clinical trials for several viral diseases with fascinating results and are commercially available for clinical use [77]. VLP vaccines are of keen interest and their further development has been warranted for good reasons. As VLPs are completely devoid of genetic material required for replication, they are extremely safe. Additionally, due to their size, enabling rapid VLP trafficking into the lymph nodes a rapid immune response induction is feasible. Moreover, the repetitive antigen presentation on the particle surface promotes potent immune response induction [78]. As with nanoparticle vaccines, T. gondii vaccine studies conducted using VLPs are limited. Some of the earliest VLP constructs displayed the inner membrane complex subcompartment protein 3 (ISP3) of T. gondii, which conferred protection in mice challenge-infected with the T. gondii ME49 strain through the intraperitoneal [79] or oral route [80]. Following suit, multiple studies have been conducted investigating the efficacy of VLP vaccines against ME49 strains using several well-characterized T. gondii antigens (Table 3). VLPs expressing either ROP4 or ROP13 T. gondii completely protected mice against a lethal dose of ME49 cysts and alleviated the inflammatory responses in their brains [81]. The protective efficacy of these VLPs was further enhanced when the two antigens were co-expressed on a single VLP, as it conferred $100 \%$ survival against a lethal challenge with ME49 strain and drastically reduced the cyst counts in mice [82]. Similar findings were reported from mice immunized with multi-antigenic VLPs expressing IMC, ROP18, and MIC8 [83]. VLPs solely expressing the AMA1 protein were not as effective as the VLPs expressing the rhoptry proteins as the protective efficacies were moderate at best [84].

Table 3. An overview of the T. gondii virus-like particle vaccines and their efficacies. Only the studies that assessed all four of the parameters listed below were selected and referenced in the table. Survival refers to the total duration of survival for immunized mice. +, weak; ++ intermediate; +++ strong.

\begin{tabular}{|c|c|c|c|c|c|c|}
\hline Vaccine Platform & Animal Model & $\begin{array}{l}\text { Antibody } \\
\text { Response }\end{array}$ & $\begin{array}{l}\text { Cellular } \\
\text { Immune } \\
\text { Response }\end{array}$ & $\begin{array}{c}\text { Parasite } \\
\text { Burden } \\
\text { Reduction }\end{array}$ & Survival & Reference \\
\hline \multicolumn{7}{|l|}{ Virus-like particles } \\
\hline ROP4, ROP13 & & ++ & ++ & +++ & ME49: 100\% & [82] \\
\hline IMC, ROP18, MIC8 & Mouse & ++ & + & +++ & ME49: 100\% & {$[85,86]$} \\
\hline ROP18+MIC8 & & ++ & + & ++ & GT1: 17 days & {$[87]$} \\
\hline $\begin{array}{l}\text { Multi-antigenic } \\
\text { epitope }\end{array}$ & & + & + & + & RH: 20 days & [88] \\
\hline
\end{tabular}

Supplementing VLP vaccines with adjuvants, as with other vaccine platforms, strengthened the protective efficacy of the vaccines. Multi-antigenic VLPs adjuvanted with the Tolllike receptor 9 agonist CpG ODN enhanced both humoral and cellular immune responses in mice and further limited cyst formation in comparison to unadjuvanted VLPs [85]. Using the identical VLP vaccine, increasing the number of immunizations was also effective at reducing the cyst counts [86].

While a large majority of the VLP-based vaccines were targeted against the ME49 strain of T. gondii, only a few studies have been conducted against type I T. gondii strains. Surprisingly, intranasal administration of a VLP vaccine expressing the MIC 8 of T. gondii conferred $100 \%$ survival when challenged with the RH strain, while intramuscular administration of the identical VLP vaccine conferred $60 \%$ survival in mice [89]. Co-immunizing VLPs with ROP18 and MIC8 significantly enhanced survival in mice when challengeinfected with the GT1 strain [87]. A multi-antigen VLP vaccine expressing IMC, ROP18, and MIC8 almost completely inhibited parasite replication and prolonged survival of mice following a GT1 challenge infection in mice [90]. Chimeric VLP constructed using the T cell and B cell epitopes on the hepatitis B virus core antigen conferred partial protection against RH and PRU strains [88]. 


\subsection{Live-Attenuated Vaccines}

Safety concerns regarding live-attenuated vaccines continue to exist and serve as a barrier for clinical trials, but their efficacies remain phenomenal. Notably, compared to other vaccine platforms, live-attenuated $T$. gondii vaccines conferred near-complete protection against multiple T. gondii strains as described in Table 4 . A vast majority of the experimental live-attenuated vaccines were designed targeting the biosynthetic pathways of T. gondii. Deleting carbamoyl phosphate synthetase II, an enzyme crucial for pyrimidine biosynthesis in T. gondii RH strain, conferred partial protection in mice [91]. Immunizing mice with the $\alpha$-amylase knockout type II ME49 mutant invoked both cellular and humoral immune response and inhibited parasite proliferation [92]. Mice immunized with the adenylosuccinate lyase-deficient ME49 were protected upon a challenge infection with the type I RH, type II ME49, and type III VEG strains [93]. Genetically engineering T. gondii using the CRISPR-Cas9 system to construct a T. gondii RH strain with a defective novel putative transporter 1 conferred heterologous protection and ensured $100 \%$ survival following a challenge infection with RH, PYS, and PRU strains [94]. T. gondii RH strain with defective Gra17 gene mutant as an attenuated vaccine provided partial protection against homologous and heterologous T. gondii strains [95].

Mice immunized with $T$. gondii $\mathrm{RH}$ tachyzoites with deleted apical membrane antigen 1 (AMA1) conferred long-lasting protective immunity against both homologous and heterologous challenge infections [96]. Immunizing mice with a T. gondii PRU strain with disrupted orotidine $5^{\prime}$-monophosphate decarboxylase (Ompdc) gene also conferred homologous and heterologous protection against both acute and chronic toxoplasmosis [97]. An attenuated ME49 strain lacking both of the lactate dehydrogenases 1 and 2 genes efficiently protected mice against a wide variety of type I, II, and III T. gondii strains [98].

Table 4. An overview of the live-attenuated T. gondii vaccine platforms and their efficacies. Only the studies that assessed all four of the parameters listed below were selected and referenced in the table. Survival refers to the total duration of survival for immunized mice. +, weak; ++ intermediate; +++ strong.

\begin{tabular}{|c|c|c|c|c|c|c|}
\hline Vaccine Platform & $\begin{array}{l}\text { Animal } \\
\text { Model }\end{array}$ & $\begin{array}{l}\text { Antibody } \\
\text { Response }\end{array}$ & $\begin{array}{l}\text { Cellular } \\
\text { Immune } \\
\text { Response }\end{array}$ & $\begin{array}{c}\text { Parasite } \\
\text { Burden } \\
\text { Reduction }\end{array}$ & Survival & Reference \\
\hline \multicolumn{7}{|l|}{ Live-attenuated } \\
\hline$\Delta \alpha$-amylase & & ++ & ++ & ++ & $\begin{array}{c}\text { RH, ME49, VEG, C7719, } \\
\text { WH1: }>90 \%\end{array}$ & [92] \\
\hline$\Delta$ Adsl & Mouse & ++ & +++ & ++ & RH, VEG, ME49: 100\% & [93] \\
\hline$\Delta \mathrm{Npt} 1$ & & ++ & +++ & +++ & RH, PYS: $100 \%$ & [94] \\
\hline$\Delta$ Gra17 & & ++ & + & +++ & RH, PRU, PYS, TgC7: 100\% & [95] \\
\hline$\Delta \mathrm{Cdpk} 2$ & & ++ & + & +++ & RH, PRU, PYS, TgC7: 100\% & [99] \\
\hline
\end{tabular}

Earlier studies have reported the potential of attenuated vaccines for preventing acute, chronic, and congenital toxoplasmosis. An attenuated PRU strain with deficient $c d p k 2$ gene was reported to protect mice from acute, chronic, and congenital toxoplasmosis following heterologous challenge infections with RH, PYS, and TgC7 strains [99]. A similar degree of protection was observed from mice immunized with $T$. gondii $\mathrm{RH}$ strain lacking tyrosine kinase-like 1 (Tkl1) [100] and also from RH tachyzoites lacking GRA17 and novel putative transporter (Npt1) genes [101].

Live-attenuated vaccines were generally highly protective when tested in murine models, and this phenomenon was also observed in other animals. Felines immunized with microneme (MIC) 1 and 3 double knock out T. gondii mutant induced T. gondii-specific antibody response but failed to prevent oocyst shedding [102]. A T. gondii mutant lacking the fertilization factor HAP2 was demonstrated to be a potential live-attenuated vaccine candidate. Inoculating this mutant parasite into cats completely prevented oocyst excretion upon a subsequent challenge with wild-type T. gondii and inhibited the establishment of systemic infection [103]. 


\subsection{Carbohydrate Vaccines}

Vaccines designed using the glycosylphosphatidylinositol (GPI) glycoconjugates were considered to be potential vaccine candidates, as they confer favorable advantages over the traditional vaccine systems. Notably, compared to the live-attenuated or the inactivated vaccines, they are much safer to use. Moreover, because mutations in these essential biosynthetic genes have devastating consequences for the parasite, resistance against these carbohydrate antigens is not likely to occur [104]. To date, T. gondii vaccine research conducted using carbohydrate or glycolipid-based vaccines is extremely rare. Recently, a study by Götze et al. [105] investigated the protective efficacy of GPI-based vaccines against $T$. gondii infection in mice. Although robust antibody responses were induced in mice post-immunization, they were not specific to the carbohydrate antigen and failed to confer adequate protection upon a lethal challenge with $T$. gondii tachyzoites [105]. Vaccines based on naturally occurring polysaccharides such as chitosan have been investigated. In one study by Teimouri et al. [106], it was reported that chitosan nanoparticles of various molecular weights were capable of inhibiting T. gondii RH tachyzoites. Further studies investigating methods that enhance the immunogenicity and protective efficacy of these carbohydrate vaccines could enable their clinical application.

\section{Limitations and Challenges to Vaccine Design}

Vaccines against toxoplasmosis can be challenging to develop as numerous factors must be taken into consideration for each of the vaccine platforms. There are lingering safety concerns involving the use of DNA vaccines, such as the potential genomic integration of the plasmid which may activate oncogenic proteins and antibody generation against the vaccine DNA itself [107]. While these safety issues are of concern, they are not the major factors hindering its emergence as commercially viable prophylaxis tools since the probability of these unintended side effects occurring in vaccine recipients is low [108]. Rather, the Achilles heel of DNA vaccines has been its low immunogenicity [109]. To this end, applying several strategies such as adjuvant inclusion could result in their clinical approval in the foreseeable future. Recombinant subunit vaccines and virus-like particles are safe but as with DNA vaccines, they are less immunogenic especially when compared to live-attenuated vaccines. Additionally, in the latter of the two, a high production cost and additional down-stream purification processes that delay production speed are some of the disadvantages associated with this method [110]. Carbohydrate-based vaccines, as with the aforementioned vaccine platforms, also faces issues involving poor immunogenicity and antibody affinity. As such, careful selection of carrier protein and conjugation methods are necessary to enhance its immunogenicity [111].

While live-attenuated T. gondii vaccines are successful and proven to be highly immunogenic in several animals, these cannot be tested in humans due to ethical issues as the possibility of attenuated vaccines reverting to their virulent wild-type form cannot be neglected. For example, safety concerns involving the use of live-attenuated oral poliovirus vaccine have been on the rise over the past few decades. The reversion of these attenuated vaccines can be fatal, especially in areas with low vaccination coverage, as it contributes to vaccine-derived poliovirus outbreaks resulting in severe cases of paralytic poliomyelitis [112]. This is particularly true for attenuated T. gondii RH or PRU strains with a deficient Ku 80 gene, whose involvement in DNA repair renders the parasite more susceptible to accumulating genetic mutations over time [113]. Moreover, in real world field settings, individuals can be exposed to multiple strains rather than a pre-defined parasite strain which renders its efficacy somewhat questionable [114]. While the three clonal lineages described earlier by Howe and Sibley [115] provided a general understanding of the population genetic structure of $T$. gondii and its correlation to clinical toxoplasmosis, this was considered to be not a true global representation of the parasite as the clinical samples reported were predominantly from the western hemisphere [116]. Evidently, a highly virulent atypical strain was isolated from a clinical case of congenital toxoplasmosis in Europe, which signified that the immunity against the clonal lineages prevalent in Europe 
may not confer protection against these atypical strains [117]. Currently, numerous atypical strains have been reported throughout the globe and several of these are estimated to possess greater pathogenicity than those reported from the clonal types [116]. Based on this notion, vaccines conferring cross-strain protective immunity should also be investigated.

\section{Conclusions and Future Perspective}

Progress in toxoplasmosis vaccine development has been ongoing for decades, but an effective vaccine for clinical use is still lacking. While various strategies have been utilized for vaccine development, variances in vaccine efficacies exist across multiple vaccine platforms. The consensus seems to be that multi-antigenic vaccines tend to be more efficacious than single antigen-expressing vaccines, irrespective of the vaccine platform used. Based on this rationale, careful selection of highly immunogenic antigens and combining them to construct a multi-antigenic vaccine on platforms such as VLPs would advance the current progress in T. gondii vaccine design and benefit both humans and other intermediate hosts. Alternatively, the possibility of oral vaccines for immunizing nonhuman intermediate hosts could be explored. Since oral vaccines are easy to administer and enable mass vaccinating to be feasible, developing an ingestible vaccine using T. gondii antigen-expressing recombinant baculoviruses is plausible. In summary, with continued multi-disciplinary efforts and the application of diverse strategies, developing a successful toxoplasmosis vaccine may be feasible in due time.

Author Contributions: Conceptualization, K.-B.C. and F.-S.Q.; writing-original draft preparation, K.-B.C.; writing-review and editing, K.-B.C. and F.-S.Q.; supervision, F.-S.Q.; funding acquisition, F.-S.Q. All authors have read and agreed to the published version of the manuscript.

Funding: This research was funded by the National Research Foundation of Korea (NRF), grant number 2018R1A6A1A03025124, and the Ministry of Health \& Welfare, Republic of Korea [HV20C0085, HV20C0142].

Institutional Review Board Statement: Not applicable.

Informed Consent Statement: Not applicable.

Data Availability Statement: Data sharing not applicable.

Conflicts of Interest: The authors declare no conflict of interest.

\section{References}

1. Halonen, S.K.; Weiss, L.M. Toxoplasmosis. Handb. Clin. Neurol. 2013, 114, 125-145. [CrossRef] [PubMed]

2. Montazeri, M.; Mehrzadi, S.; Sharif, M.; Sarvi, S.; Tanzifi, A.; Aghayan, S.A.; Daryani, A. Drug Resistance in Toxoplasma gondii. Front. Microbiol. 2018, 9, 2587. [CrossRef]

3. Dunay, I.R.; Gajurel, K.; Dhakal, R.; Liesenfeld, O.; Montoya, J.G. Treatment of Toxoplasmosis: Historical Perspective, Animal Models, and Current Clinical Practice. Clin. Microbiol. Rev. 2018, 31. [CrossRef] [PubMed]

4. Wang, J.L.; Zhang, N.Z.; Li, T.T.; He, J.J.; Elsheikha, H.M.; Zhu, X.Q. Advances in the Development of Anti-Toxoplasma gondii Vaccines: Challenges, Opportunities, and Perspectives. Trends Parasitol. 2019, 35, 239-253. [CrossRef]

5. Gallant, J. Get Rich Quick with Old Generic Drugs! The Pyrimethamine Pricing Scandal. Open Forum Infect. Dis. 2015, 2, ofv177. [CrossRef] [PubMed]

6. Rémy, V.; Zöllner, Y.; Heckmann, U. Vaccination: The cornerstone of an efficient healthcare system. J. Mark. Access Health Policy 2015, 3. [CrossRef] [PubMed]

7. Dubey, J.P. Toxoplasmosis in sheep-The last 20 years. Vet. Parasitol. 2009, 163, 1-14. [CrossRef]

8. Li, Y.; Zhou, H. Moving towards improved vaccines for Toxoplasma gondii. Expert Opin. Biol. Ther. 2018, 18, 273-280. [CrossRef]

9. Sonaimuthu, P.; Ching, X.T.; Fong, M.Y.; Kalyanasundaram, R.; Lau, Y.L. Induction of Protective Immunity against Toxoplasmosis in BALB/c Mice Vaccinated with Toxoplasma gondii Rhoptry-1. Front. Microbiol. 2016, 7, 808. [CrossRef]

10. Alizadeh, P.; Ahmadpour, E.; Daryani, A.; Kazemi, T.; Spotin, A.; Mahami-Oskouei, M.; Flynn, R.J.; Azadi, Y.; Rajabi, S.; Sandoghchian, S. IL-17 and IL-22 elicited by a DNA vaccine encoding ROP13 associated with protection against Toxoplasma gondii in BALB/c mice. J. Cell. Physiol. 2019, 234, 10782-10788. [CrossRef]

11. Li, X.Z.; Lv, L.; Zhang, X.; Anchang, K.Y.; Abdullahi, A.Y.; Tu, L.; Wang, X.; Xia, L.; Zhang, X.X.; Feng, W.; et al. Recombinant canine adenovirus type-2 expressing TgROP16 provides partial protection against acute Toxoplasma gondii infection in mice. Infect. Genet. Evol. 2016, 45, 447-453. [CrossRef] 
12. Rashid, I.; Moiré, N.; Héraut, B.; Dimier-Poisson, I.; Mévélec, M.N. Enhancement of the protective efficacy of a ROP18 vaccine against chronic toxoplasmosis by nasal route. Med. Microbiol. Immunol. 2017, 206, 53-62. [CrossRef]

13. Yang, W.B.; Zhou, D.H.; Zou, Y.; Chen, K.; Liu, Q.; Wang, J.L.; Zhu, X.Q.; Zhao, G.H. Vaccination with a DNA vaccine encoding Toxoplasma gondii ROP54 induces protective immunity against toxoplasmosis in mice. Acta Trop. 2017, 176, 427-432. [CrossRef]

14. Zhang, Z.; Li, Y.; Wang, M.; Xie, Q.; Li, P.; Zuo, S.; Kong, L.; Wang, C.; Wang, S. Immune Protection of Rhoptry Protein 21 (ROP21) of Toxoplasma gondii as a DNA Vaccine Against Toxoplasmosis. Front. Microbiol. 2018, 9, 909. [CrossRef] [PubMed]

15. Ching, X.T.; Fong, M.Y.; Lau, Y.L. Evaluation of the Protective Effect of Deoxyribonucleic Acid Vaccines Encoding Granule Antigen 2 and 5 Against Acute Toxoplasmosis in BALB/c Mice. Am. J. Trop. Med. Hyg. 2017, 96, 1441-1447. [CrossRef]

16. Hu, L.Y.; Zhang, N.Z.; Zhang, F.K.; Wang, M.; Gao, Q.; Wang, J.L.; Zhu, X.Q. Resistance to Chronic Toxoplasma gondii Infection Induced by a DNA Vaccine Expressing GRA16. Biomed. Res. Int. 2017, 2017, 1295038. [CrossRef]

17. Zheng, B.; Lou, D.; Ding, J.; Zhuo, X.; Ding, H.; Kong, Q.; Lu, S. GRA24-Based DNA Vaccine Prolongs Survival in Mice Challenged with a Virulent Toxoplasma gondii Strain. Front. Immunol. 2019, 10, 418. [CrossRef]

18. Li, Z.Y.; Lu, J.; Zhang, N.Z.; Elsheikha, H.M.; Hou, J.L.; Guo, H.T.; Zhu, X.Q. Immunization with plasmid DNA expressing Heat Shock Protein 40 confers prophylactic protection against chronic Toxoplasma gondii infection in Kunming mice. Parasite 2018, 25, 37. [CrossRef]

19. Zheng, B.; Ding, J.; Lou, D.; Tong, Q.; Zhuo, X.; Ding, H.; Kong, Q.; Lu, S. The Virulence-Related MYR1 Protein of Toxoplasma gondii as a Novel DNA Vaccine against Toxoplasmosis in Mice. Front. Microbiol. 2019, 10, 734. [CrossRef]

20. Huang, S.Y.; Chen, K.; Wang, J.L.; Yang, B.; Zhu, X.Q. Evaluation of protective immunity induced by recombinant calciumdependent protein kinase 1 (TgCDPK1) protein against acute toxoplasmosis in mice. Microb. Pathog. 2019, 133, 103560. [CrossRef]

21. Chen, K.; Wang, J.L.; Huang, S.Y.; Yang, W.B.; Zhu, W.N.; Zhu, X.Q. Immune responses and protection after DNA vaccination against Toxoplasma gondii calcium-dependent protein kinase 2 (TgCDPK2). Parasite 2017, 24, 41. [CrossRef]

22. Zhang, N.Z.; Gao, Q.; Wang, M.; Hou, J.L.; Zhang, F.K.; Hu, L.Y.; Zhu, X.Q. Protective Efficacy Against Acute and Chronic Toxoplasma gondii Infection Induced by Immunization with the DNA Vaccine TgDOC2C. Front. Microbiol. 2018, 9, 2965. [CrossRef] [PubMed]

23. Ahmadpour, E.; Sarvi, S.; Soteh, M.B.H.; Sharif, M.; Rahimi, M.T.; Valadan, R.; Tehrani, M.; Khalilian, A.; Montazeri, M.; Daryani, A. Evaluation of the immune response in BALB/c mice induced by a novel DNA vaccine expressing GRA14 against Toxoplasma gondii. Parasite Immunol. 2017, 39. [CrossRef]

24. Ahmadpour, E.; Sarvi, S.; Soteh, M.B.H.; Sharif, M.; Rahimi, M.T.; Valadan, R.; Tehrani, M.; Khalilian, A.; Montazeri, M.; Fasihi-Ramandi, M.; et al. Enhancing immune responses to a DNA vaccine encoding Toxoplasma gondii GRA14 by calcium phosphate nanoparticles as an adjuvant. Immunol. Lett. 2017, 185, 40-47. [CrossRef] [PubMed]

25. Lu, G.; Zhou, J.; Zhao, Y.H.; Wang, L. DNA vaccine ROP29 from Toxoplasma gondii containing R848 enhances protective immunity in mice. Parasite Immunol. 2018, 40, e12578. [CrossRef]

26. Foroutan, M.; Barati, M.; Ghaffarifar, F. Enhancing immune responses by a novel multi-epitope ROP8 DNA vaccine plus interleukin-12 plasmid as a genetic adjuvant against acute Toxoplasma gondii infection in BALB/c mice. Microb. Pathog. 2020, 147, 104435. [CrossRef]

27. Mavi, S.A.; Modarressi, M.H.; Mohebali, M.; Shojaee, S.; Zeraati, H.; Teimouri, A.; Keshavarz, H. Assessment of the immunogenicity and protective efficiency of a novel dual-promoter DNA vaccine, harboring SAG1 and GRA7 genes, from RH strain of Toxoplasma gondii in BALB/c mice. Infect. Drug Resist. 2019, 12, 2519-2530. [CrossRef] [PubMed]

28. Zhu, Y.C.; He, Y.; Liu, J.F.; Chen, J. Adjuvantic cytokine IL-33 improves the protective immunity of cocktailed DNA vaccine of ROP5 and ROP18 against Toxoplasma gondii infection in mice. Parasite 2020, 27, 26. [CrossRef]

29. Sun, H.; Li, J.; Xiao, T.; Huang, X.D.; Wang, L.J.; Huang, B.C.; Yin, K.; Liu, G.Z.; Xu, C.; Wei, Q.K. Protective immunity induced by a DNA vaccine cocktail expressing TgSAG1, TgROP2, and the genetic adjuvant HBsAg against Toxoplasma gondii infection. Microb. Pathog. 2020, 147, 104441. [CrossRef]

30. Pagheh, A.S.; Daryani, A.; Alizadeh, P.; Hassannia, H.; Oliveira, S.M.R.; Kazemi, T.; Rezaei, F.; Pereira, M.L.; Ahmadpour, E. Protective effect of a DNA vaccine cocktail encoding ROP13 and GRA14 with Alum nano-adjuvant against Toxoplasma gondii infection in mice. Int. J. Biochem. Cell Biol. 2021, 132, 105920. [CrossRef]

31. Zhang, N.Z.; Gao, Q.; Wang, M.; Elsheikha, H.M.; Wang, B.; Wang, J.L.; Zhang, F.K.; Hu, L.Y.; Zhu, X.Q. Immunization with a DNA Vaccine Cocktail Encoding TgPF, TgROP16, TgROP18, TgMIC6, and TgCDPK3 Genes Protects Mice Against Chronic Toxoplasmosis. Front. Immunol. 2018, 9, 1505. [CrossRef]

32. Xu, X.P.; Liu, W.G.; Xu, Q.M.; Zhu, X.Q.; Chen, J. Evaluation of immune protection against Toxoplasma gondii infection in mice induced by a multi-antigenic DNA vaccine containing TgGRA24, TgGRA25 and TgMIC6. Parasite 2019, 26, 58. [CrossRef]

33. Chahal, J.S.; Khan, O.F.; Cooper, C.L.; McPartlan, J.S.; Tsosie, J.K.; Tilley, L.D.; Sidik, S.M.; Lourido, S.; Langer, R.; Bavari, S.; et al. Dendrimer-RNA nanoparticles generate protective immunity against lethal Ebola, H1N1 influenza, and Toxoplasma gondii challenges with a single dose. Proc. Natl. Acad. Sci. USA 2016, 113, E4133-E4142. [CrossRef] [PubMed]

34. Wang, W.; Feng, F.; Lv, J.; Xie, Z.; Chen, J.; Zhang, L.; Li, W. Major Immunodominant Region of Hepatitis B Virus Core Antigen as a Delivery Vector to Improve the Immunogenicity of the Fusion Antigen ROP2-SAG1 Multiepitope from Toxoplasma gondii in Mice. Viral Immunol. 2017, 30, 508-515. [CrossRef]

35. Zhang, D.; Jiang, N.; Chen, Q. Vaccination with recombinant adenoviruses expressing Toxoplasma gondii MIC3, ROP9, and SAG2 provide protective immunity against acute toxoplasmosis in mice. Vaccine 2019, 37, 1118-1125. [CrossRef] [PubMed] 
36. Zheng, L.; Hu, Y.; Hua, Q.; Luo, F.; Xie, G.; Li, X.; Lin, J.; Wan, Y.; Ren, S.; Pan, C.; et al. Protective immune response in mice induced by a suicidal DNA vaccine encoding NTPase-II gene of Toxoplasma gondii. Acta Trop. 2017, 166, 336-342. [CrossRef] [PubMed]

37. Luo, F.; Zheng, L.; Hu, Y.; Liu, S.; Wang, Y.; Xiong, Z.; Hu, X.; Tan, F. Induction of Protective Immunity against Toxoplasma gondii in Mice by Nucleoside Triphosphate Hydrolase-II (NTPase-II) Self-amplifying RNA Vaccine Encapsulated in Lipid Nanoparticle (LNP). Front. Microbiol. 2017, 8, 605. [CrossRef]

38. Maeta, M.; Miura, N.; Tanaka, H.; Nakamura, T.; Kawanishi, R.; Nishikawa, Y.; Asano, K.; Tanaka, M.; Tamagawa, S.; Nakai, Y.; et al. Vitamin E Scaffolds of pH-Responsive Lipid Nanoparticles as DNA Vaccines in Cancer and Protozoan Infection. Mol. Pharm. 2020, 17, 1237-1247. [CrossRef]

39. Wang, T.; Yin, H.; Li, Y.; Zhao, L.; Sun, X.; Cong, H. Vaccination with recombinant adenovirus expressing multi-stage antigens of Toxoplasma gondii by the mucosal route induces higher systemic cellular and local mucosal immune responses than with other vaccination routes. Parasite 2017, 24, 12. [CrossRef]

40. El Bissati, K.; Chentoufi, A.A.; Krishack, P.A.; Zhou, Y.; Woods, S.; Dubey, J.P.; Vang, L.; Lykins, J.; Broderick, K.E.; Mui, E.; et al. Adjuvanted multi-epitope vaccines protect HLA-A*11:01 transgenic mice against Toxoplasma gondii. JCI Insight 2016, 1, e85955. [CrossRef]

41. Zheng, B.; Ding, J.; Chen, X.; Yu, H.; Lou, D.; Tong, Q.; Kong, Q.; Lu, S. Immuno-Efficacy of a T. gondii Secreted Protein with an Altered Thrombospondin Repeat (TgSPATR) As a Novel DNA Vaccine Candidate against Acute Toxoplasmosis in BALB/c Mice. Front. Microbiol. 2017, 8, 216. [CrossRef] [PubMed]

42. Zhou, J.; Wang, L. SAG4 DNA and Peptide Vaccination Provides Partial Protection against T. gondii Infection in BALB/c Mice. Front. Microbiol. 2017, 8, 1733. [CrossRef] [PubMed]

43. Pagheh, A.S.; Sarvi, S.; Gholami, S.; Asgarian-Omran, H.; Valadan, R.; Hassannia, H.; Ahmadpour, E.; Fasihi-Ramandie, M.; Dodangeh, S.; Hosseni-Khah, Z.; et al. Protective efficacy induced by DNA prime and recombinant protein boost vaccination with Toxoplasma gondii GRA14 in mice. Microb. Pathog. 2019, 134, 103601. [CrossRef]

44. Vartak, A.; Sucheck, S.J. Recent Advances in Subunit Vaccine Carriers. Vaccines 2016, 4, 12. [CrossRef] [PubMed]

45. da Costa, A.; Zorgi, N.E.; do Nascimento, N.; Galisteo, A.J.J.; de Andrade, H.F.J. Gamma irradiation of Toxoplasma gondii protein extract improve immune response and protection in mice models. Biomed. Pharmacother. 2018, 106, 599-604. [CrossRef] [PubMed]

46. Da Costa, A.; Nascimento, N.D.; Galisteo, A.J.; Passos, A.B.D.D.; de Andrade, H.F. Radiation effects on Toxoplasma antigens: Different immune responses of irradiated intact tachyzoites or soluble antigens in experimental mice models. Int. J. Radiat. Biol. 2020, 96, 697-706. [CrossRef]

47. Rahman, M.; Devriendt, B.; Algaba, I.G.; Verhaegen, B.; Dorny, P.; Dierick, K.; Cox, E. QuilA-Adjuvanted T. gondii Lysate Antigens Trigger Robust Antibody and IFN $\gamma+$ T Cell Responses in Pigs Leading to Reduction in Parasite DNA in Tissues Upon Challenge Infection. Front. Immunol. 2019, 10, 2223. [CrossRef]

48. Roozbehani, M.; Falak, R.; Mohammadi, M.; Hemphill, A.; Razmjou, E.; Meamar, A.R.; Masoori, L.; Khoshmirsafa, M.; Moradi, M.; Gharavi, M.J. Characterization of a multi-epitope peptide with selective MHC-binding capabilities encapsulated in PLGA nanoparticles as a novel vaccine candidate against Toxoplasma gondii infection. Vaccine 2018, 36, 6124-6132. [CrossRef]

49. Guo, J.; Sun, X.; Yin, H.; Wang, T.; Li, Y.; Zhou, C.; Zhou, H.; He, S.; Cong, H. Chitosan Microsphere Used as an Effective System to Deliver a Linked Antigenic Peptides Vaccine Protect Mice Against Acute and Chronic Toxoplasmosis. Front. Cell. Infect. Microbiol. 2018, 8, 163. [CrossRef]

50. Fereig, R.M.; Kuroda, Y.; Terkawi, M.A.; Mahmoud, M.E.; Nishikawa, Y. Immunization with Toxoplasma gondii peroxiredoxin 1 induces protective immunity against toxoplasmosis in mice. PLoS ONE 2017, 12, e0176324. [CrossRef]

51. Liu, K.; Wen, H.; Cai, H.; Wu, M.; An, R.; Chu, D.; Yu, L.; Shen, J.; Chen, L.; Du, J. Protective Effect Against Toxoplasmosis in BALB/c Mice Vaccinated with Toxoplasma gondii Macrophage Migration Inhibitory Factor. Front. Microbiol. 2019, 10, 813. [CrossRef]

52. Liu, Z.; Yuan, F.; Yang, Y.; Yin, L.; Liu, Y.; Wang, Y.; Zheng, K.; Cao, J. Partial protective immunity against toxoplasmosis in mice elicited by recombinant Toxoplasma gondii malate dehydrogenase. Vaccine 2016, 34, 989-994. [CrossRef] [PubMed]

53. Liu, Z.; Yin, L.; Li, Y.; Yuan, F.; Zhang, X.; Ma, J.; Liu, H.; Wang, Y.; Zheng, K.; Cao, J. Intranasal immunization with recombinant Toxoplasma gondii actin depolymerizing factor confers protective efficacy against toxoplasmosis in mice. BMC Immunol. 2016, 17, 37. [CrossRef]

54. Wu, M.; An, R.; Chen, Y.; Chen, T.; Wen, H.; Yan, Q.; Shen, J.; Chen, L.; Du, J. Vaccination with recombinant Toxoplasma gondii CDPK3 induces protective immunity against experimental toxoplasmosis. Acta Trop. 2019, 199, 105148. [CrossRef] [PubMed]

55. Zhang, Z.; Li, Y.; Li, H.; Song, X.; Ma, Z.; Lu, H.; Liu, S.; Zhao, Y.; Tan, M.; Wang, S.; et al. Identification of Toxoplasma gondii Tyrosine Hydroxylase (TH) Activity and Molecular Immunoprotection against Toxoplasmosis. Vaccines 2020, 8, 158. [CrossRef] [PubMed]

56. Li, Z.Y.; Guo, H.T.; Calderón-Mantilla, G.; He, J.J.; Wang, J.L.; Bonev, B.B.; Zhu, X.Q.; Elsheikha, H.M. Immunostimulatory efficacy and protective potential of putative TgERK7 protein in mice experimentally infected by Toxoplasma gondii. Int. J. Med. Microbiol. 2020, 310, 151432. [CrossRef] [PubMed]

57. Dimier-Poisson, I.; Carpentier, R.; N'Guyen, T.T.; Dahmani, F.; Ducournau, C.; Betbeder, D. Porous nanoparticles as delivery system of complex antigens for an effective vaccine against acute and chronic Toxoplasma gondii infection. Biomaterials 2015, 50, 164-175. [CrossRef] [PubMed] 
58. Yu, Z.; Zhou, T.; Luo, Y.; Dong, L.; Li, C.; Liu, J.; Luo, J.; Yan, R.; Xu, L.; Song, X.; et al. Modulation Effects of Toxoplasma gondii Histone H2A1 on Murine Macrophages and Encapsulation with Polymer as a Vaccine Candidate. Vaccines 2020, 8, 731. [CrossRef]

59. Chuang, S.C.; Chung, Y.C.; Yang, C.D. Protective immunity against toxoplasmosis in mice induced by single-dose immunization with rSAG1/2 protein released from poly(lactide-co-glycolide) microparticles. Parasite 2017, 24, 5. [CrossRef]

60. Czarnewski, P.; Araújo, E.C.B.; Oliveira, M.C.; Mineo, T.W.P.; Silva, N.M. Recombinant TgHSP70 Immunization Protects against Toxoplasma gondii Brain Cyst Formation by Enhancing Inducible Nitric Oxide Expression. Front. Cell. Infect. Microbiol. $2017,7,142$. [CrossRef]

61. Ching, X.T.; Fong, M.Y.; Lau, Y.L. Evaluation of Immunoprotection Conferred by the Subunit Vaccines of GRA2 and GRA5 against Acute Toxoplasmosis in BALB/c Mice. Front. Microbiol. 2016, 7, 609. [CrossRef] [PubMed]

62. Bastos, L.M.; Macêdo, A.G.; Silva, M.V.; Santiago, F.M.; Ramos, E.L.; Santos, F.A.; Pirovani, C.P.; Goulart, L.R.; Mineo, T.W.; Mineo, J.R. Toxoplasma gondii-Derived Synthetic Peptides Containing B- and T-Cell Epitopes from GRA2 Protein Are Able to Enhance Mice Survival in a Model of Experimental Toxoplasmosis. Front. Cell. Infect. Microbiol. 2016, 6, 59. [CrossRef] [PubMed]

63. Gatkowska, J.; Dzitko, K.; Ferra, B.T.; Holec-Gassior, L.; Kawka, M.; Dziadek, B. The Immunogenic and Immunoprotective Activities of Recombinant Chimeric T. gondii Proteins Containing AMA1 Antigen Fragments. Vaccines 2020, 8, 724. [CrossRef] [PubMed]

64. Zhao, G.; Song, X.; Kong, X.; Zhang, N.; Qu, S.; Zhu, W.; Yang, Y.; Wang, Q. Immunization with Toxoplasma gondii aspartic protease 3 increases survival time of infected mice. Acta Trop. 2017, 171, 17-23. [CrossRef] [PubMed]

65. Wang, L.J.; Xiao, T.; Xu, C.; Li, J.; Liu, G.Z.; Yin, K.; Cui, Y.; Wei, Q.K.; Huang, B.C.; Sun, H. Protective immune response against Toxoplasma gondii elicited by a novel yeast-based vaccine with microneme protein 16. Vaccine 2018, 36, 3943-3948. [CrossRef] [PubMed]

66. Sánchez-López, E.F.; Corigliano, M.G.; Albarracín, R.M.; Sander, V.A.; Legarralde, A.; Bengoa-Luoni, S.A.; Clemente, M. Plant Hsp90 is a novel adjuvant that elicits a strong humoral and cellular immune response against B- and T-cell epitopes of a Toxoplasma gondii SAG1 peptide. Parasites Vectors 2019, 12, 140. [CrossRef] [PubMed]

67. Lakhrif, Z.; Moreau, A.; Hérault, B.; Di-Tommaso, A.; Juste, M.; Moiré, N.; Dimier-Poisson, I.; Mévélec, M.N.; Aubrey, N. Targeted Delivery of Toxoplasma gondii Antigens to Dendritic Cells Promote Immunogenicity and Protective Efficiency against Toxoplasmosis. Front. Immunol. 2018, 9, 317. [CrossRef]

68. Arcon, N.; Picchio, M.S.; Fenoy, I.M.; Moretta, R.E.; Soto, A.S.; Sibilia, M.D.P.; Sánchez, V.R.; Prato, C.A.; Tribulatti, M.V.; Goldman, A.; et al. Synergistic effect of GRA7 and profilin proteins in vaccination against chronic Toxoplasma gondii infection. Vaccine 2021, 39, 933-942. [CrossRef]

69. Lung, P.; Yang, J.; Li, Q. Nanoparticle formulated vaccines: Opportunities and challenges. Nanoscale 2020, $12,5746-5763$. [CrossRef]

70. El Bissati, K.; Zhou, Y.; Paulillo, S.M.; Raman, S.K.; Karch, C.P.; Roberts, C.W.; Lanar, D.E.; Reed, S.; Fox, C.; Carter, D.; et al. Protein nanovaccine confers robust immunity against Toxoplasma. NPJ Vaccines 2017, 2, 24. [CrossRef]

71. El Bissati, K.; Zhou, Y.; Paulillo, S.M.; Raman, S.K.; Karch, C.P.; Reed, S.; Estes, A.; Estes, A.; Lykins, J.; Burkhard, P.; et al. Engineering and characterization of a novel Self Assembling Protein for Toxoplasma peptide vaccine in HLA-A*11:01, HLA-A*02:01 and HLA-B*07:02 transgenic mice. Sci. Rep. 2020, 10, 16984. [CrossRef]

72. Ducournau, C.; Nguyen, T.T.; Carpentier, R.; Lantier, I.; Germon, S.; Précausta, F.; Pisella, P.J.; Leroux, H.; Van Langendonck, N.; Betbeder, D.; et al. Synthetic parasites: A successful mucosal nanoparticle vaccine against Toxoplasma congenital infection in mice. Futur. Microbiol. 2017, 12, 393-405. [CrossRef] [PubMed]

73. Ducournau, C.; Moiré, N.; Carpentier, R.; Cantin, P.; Herkt, C.; Lantier, I.; Betbeder, D.; Dimier-Poisson, I. Effective NanoparticleBased Nasal Vaccine Against Latent and Congenital Toxoplasmosis in Sheep. Front. Immunol. 2020, 11, 2183. [CrossRef] [PubMed]

74. Adeyemi, O.S.; Murata, Y.; Sugi, T.; Kato, K. Inorganic nanoparticles kill Toxoplasma gondii via changes in redox status and mitochondrial membrane potential. Int. J. Nanomed. 2017, 12, 1647-1661. [CrossRef]

75. Adeyemi, O.S.; Molefe, N.I.; Awakan, O.J.; Nwonuma, C.O.; Alejolowo, O.O.; Olaolu, T.; Maimako, R.F.; Suganuma, K.; Han, Y.; Kato, K. Metal nanoparticles restrict the growth of protozoan parasites. Artif. Cells Nanomed. Biotechnol. 2018, 46, S86-S94. [CrossRef]

76. Costa, I.N.; Ribeiro, M.; Franco, P.S.; da Silva, R.J.; de Araújo, T.E.; Milián, I.C.B.; Luz, L.C.; Guirelli, P.M.; Nakazato, G.; Mineo, J.R.; et al. Biogenic Silver Nanoparticles Can Control Toxoplasma gondii Infection in Both Human Trophoblast Cells and Villous Explants. Front. Microbiol. 2020, 11, 623947. [CrossRef]

77. Kushnir, N.; Streatfield, S.J.; Yusibov, V. Virus-like particles as a highly efficient vaccine platform: Diversity of targets and production systems and advances in clinical development. Vaccine 2012, 31, 58-83. [CrossRef]

78. Chu, K.B.; Quan, F.S. Virus-Like Particle Vaccines against Respiratory Viruses and Protozoan Parasites. Curr. Top. Microbiol. Immunol. 2021. [CrossRef]

79. Lee, D.H.; Kim, A.R.; Lee, S.H.; Quan, F.S. Cross-protection induced by Toxoplasma gondii virus-like particle vaccine upon intraperitoneal route challenge. Acta Trop. 2016, 164, 77-83. [CrossRef] [PubMed]

80. Lee, D.H.; Lee, S.H.; Kim, A.R.; Quan, F.S. Virus-Like Nanoparticle Vaccine Confers Protection against Toxoplasma gondii. PLoS ONE 2016, 11, e0161231. [CrossRef]

81. Kang, H.J.; Chu, K.B.; Lee, S.H.; Kim, M.J.; Park, H.; Jin, H.; Moon, E.K.; Quan, F.S. Toxoplasma gondii virus-like particle vaccination alleviates inflammatory response in the brain upon T. gondii infection. Parasite Immunol. 2020, 42, e12716. [CrossRef] 
82. Kang, H.J.; Lee, S.H.; Kim, M.J.; Chu, K.B.; Lee, D.H.; Chopra, M.; Choi, H.J.; Park, H.; Jin, H.; Quan, F.S. Influenza Virus-Like Particles Presenting both Toxoplasma gondii ROP4 and ROP13 Enhance Protection against T. gondii Infection. Pharmaceutics 2019, 11, 342. [CrossRef]

83. Lee, S.H.; Chu, K.B.; Kang, H.J.; Quan, F.S. Virus-like particles containing multiple antigenic proteins of Toxoplasma gondii induce memory T cell and B cell responses. PLoS ONE 2019, 14, e220865. [CrossRef]

84. Kim, M.J.; Lee, S.H.; Kang, H.J.; Chu, K.B.; Park, H.; Jin, H.; Moon, E.K.; Kim, S.S.; Quan, F.S. Virus-like particle vaccine displaying Toxoplasma gondii apical membrane antigen 1 induces protection against T. gondii ME49 infection in mice. Microb. Pathog. 2020, 142, 104090. [CrossRef] [PubMed]

85. Kang, H.J.; Chu, K.B.; Kim, M.J.; Lee, S.H.; Park, H.; Jin, H.; Moon, E.K.; Quan, F.S. Protective immunity induced by CpG ODN-adjuvanted virus-like particles containing Toxoplasma gondii proteins. Parasite Immunol. 2021, 43, e12799. [CrossRef]

86. Kang, H.J.; Chu, K.B.; Kim, M.J.; Park, H.; Jin, H.; Lee, S.H.; Moon, E.K.; Quan, F.S. Evaluation of CpG-ODN-Adjuvanted Toxoplasma gondii Virus-Like Particle Vaccine upon One, Two, and Three Immunizations. Pharmaceutics 2020, $12,989$. [CrossRef] [PubMed]

87. Lee, S.H.; Kang, H.J.; Lee, D.H.; Kang, S.M.; Quan, F.S. Virus-like particle vaccines expressing Toxoplasma gondii rhoptry protein 18 and microneme protein 8 provide enhanced protection. Vaccine 2018, 36, 5692-5700. [CrossRef] [PubMed]

88. Guo, J.; Zhou, A.; Sun, X.; Sha, W.; Ai, K.; Pan, G.; Zhou, C.; Zhou, H.; Cong, H.; He, S. Immunogenicity of a Virus-Like-Particle Vaccine Containing Multiple Antigenic Epitopes of Toxoplasma gondii Against Acute and Chronic Toxoplasmosis in Mice. Front. Immunol. 2019, 10, 592. [CrossRef] [PubMed]

89. Lee, S.H.; Kim, A.R.; Lee, D.H.; Rubino, I.; Choi, H.J.; Quan, F.S. Protection induced by virus-like particles containing Toxoplasma gondii microneme protein 8 against highly virulent RH strain of Toxoplasma gondii infection. PLoS ONE 2017, 12, e0175644. [CrossRef] [PubMed]

90. Lee, S.H.; Kang, H.J.; Lee, D.H.; Quan, F.S. Protective Immunity Induced by Incorporating Multiple Antigenic Proteins of Toxoplasma gondii Into Influenza Virus-Like Particles. Front. Immunol. 2018, 9, 3073. [CrossRef]

91. Zhuo, X.; Du, K.; Ding, H.; Lou, D.; Zheng, B.; Lu, S. A Carbamoyl Phosphate Synthetase II (CPSII) Deletion Mutant of Toxoplasma gondii Induces Partial Protective Immunity in Mice. Front. Microbiol. 2020, 11, 616688. [CrossRef]

92. Yang, J.; Yang, C.; Qian, J.; Li, F.; Zhao, J.; Fang, R. Toxoplasma gondii $\alpha$-amylase deletion mutant is a promising vaccine against acute and chronic toxoplasmosis. Microb. Biotechnol. 2020, 13, 2057-2069. [CrossRef] [PubMed]

93. Wang, L.; Tang, D.; Yang, C.; Yang, J.; Fang, R. Toxoplasma gondii ADSL Knockout Provides Excellent Immune Protection against a Variety of Strains. Vaccines 2020, 8, 16. [CrossRef] [PubMed]

94. Yang, W.B.; Wang, J.L.; Gui, Q.; Zou, Y.; Chen, K.; Liu, Q.; Liang, Q.L.; Zhu, X.Q.; Zhou, D.H. Immunization With a LiveAttenuated RH: $\mathrm{NPT} 1$ Strain of Toxoplasma gondii Induces Strong Protective Immunity Against Toxoplasmosis in Mice. Front. Microbiol. 2019, 10, 1875. [CrossRef] [PubMed]

95. Wang, J.L.; Elsheikha, H.M.; Zhu, W.N.; Chen, K.; Li, T.T.; Yue, D.M.; Zhang, X.X.; Huang, S.Y.; Zhu, X.Q. Immunization with Toxoplasma gondii GRA17 Deletion Mutant Induces Partial Protection and Survival in Challenged Mice. Front. Immunol. 2017, 8, 730. [CrossRef]

96. Lagal, V.; Dinis, M.; Cannella, D.; Bargieri, D.; Gonzalez, V.; Andenmatten, N.; Meissner, M.; Tardieux, I. AMA1-Deficient Toxoplasma gondii Parasites Transiently Colonize Mice and Trigger an Innate Immune Response that Leads to Long-Lasting Protective Immunity. Infect. Immun. 2015, 83, 2475-2486. [CrossRef] [PubMed]

97. Fox, B.A.; Bzik, D.J. Nonreplicating, cyst-defective type II Toxoplasma gondii Vaccine Strains Stimulate Protective Immunity against Acute and Chronic Infection. Infect. Immun. 2015, 83, 2148-2155. [CrossRef]

98. Xia, N.; Zhou, T.; Liang, X.; Ye, S.; Zhao, P.; Yang, J.; Zhou, Y.; Zhao, J.; Shen, B. A Lactate Fermentation Mutant of Toxoplasma Stimulates Protective Immunity against Acute and Chronic Toxoplasmosis. Front. Immunol. 2018, 9, 1814. [CrossRef]

99. Wang, J.L.; Li, T.T.; Elsheikha, H.M.; Chen, K.; Cong, W.; Yang, W.B.; Bai, M.J.; Huang, S.Y.; Zhu, X.Q. Live Attenuated Pru: $\Delta c d p k 2$ Strain of Toxoplasma gondii Protects Against Acute, Chronic, and Congenital Toxoplasmosis. J. Infect. Dis. 2018, 218, 768-777. [CrossRef]

100. Wang, J.L.; Liang, Q.L.; Li, T.T.; He, J.J.; Bai, M.J.; Cao, X.Z.; Elsheikha, H.M.; Zhu, X.Q. Toxoplasma gondii tkl1 Deletion Mutant Is a Promising Vaccine against Acute, Chronic, and Congenital Toxoplasmosis in Mice. J. Immunol. 2020, 204, 1562-1570. [CrossRef] [PubMed]

101. Liang, Q.L.; Sun, L.X.; Elsheikha, H.M.; Cao, X.Z.; Nie, L.B.; Li, T.T.; Li, T.S.; Zhu, X.Q.; Wang, J.L. RH $\Delta$ gra17 $\Delta$ npt1 Strain of Toxoplasma gondii Elicits Protective Immunity Against Acute, Chronic and Congenital Toxoplasmosis in Mice. Microorganisms 2020, 8, 352. [CrossRef]

102. Le Roux, D.; Djokic, V.; Morisse, S.; Chauvin, C.; Doré, V.; Lagrée, A.C.; Voisin, D.; Villain, Y.; Grasset-Chevillot, A.; Boursin, F.; et al. Evaluation of immunogenicity and protection of the Mic1-3 knockout Toxoplasma gondii live attenuated strain in the feline host. Vaccine 2020, 38, 1457-1466. [CrossRef]

103. Ramakrishnan, C.; Maier, S.; Walker, R.A.; Rehrauer, H.; Joekel, D.E.; Winiger, R.R.; Basso, W.U.; Grigg, M.E.; Hehl, A.B.; Deplazes, P.; et al. An experimental genetically attenuated live vaccine to prevent transmission of Toxoplasma gondii by cats. Sci. Rep. 2019, 9, 1474. [CrossRef]

104. Maeda, Y.; Kinoshita, T. Structural remodeling, trafficking and functions of glycosylphosphatidylinositol-anchored proteins. Prog. Lipid Res. 2011, 50, 411-424. [CrossRef] 
105. Götze, S.; Reinhardt, A.; Geissner, A.; Azzouz, N.; Tsai, Y.-H.; Kurucz, R.; Silva, D.V.; Seeberger, P.H. Investigation of the protective properties of glycosylphosphatidylinositol-based vaccine candidates in a Toxoplasma gondii mouse challenge model. Glycobiology 2015, 25, 984-991. [CrossRef]

106. Teimouri, A.; Azami, S.J.; Keshavarz, H.; Esmaeili, F.; Alimi, R.; Mavi, S.A.; Shojaee, S. Anti-Toxoplasma activity of various molecular weights and concentrations of chitosan nanoparticles on tachyzoites of RH strain. Int J. Nanomed. 2018, 13, 1341-1351. [CrossRef] [PubMed]

107. Myhr, A.I. DNA Vaccines: Regulatory Considerations and Safety Aspects. Curr. Issues Mol. Biol. 2017, 22, 79-88. [CrossRef] [PubMed]

108. Robinson, H.L.; Pertmer, T.M. DNA vaccines for viral infections: Basic studies and applications. Adv. Virus Res. 2000, 55, 1-74. [CrossRef] [PubMed]

109. Li, L.; Saade, F.; Petrovsky, N. The future of human DNA vaccines. J. Biotechnol. 2012, 162, 171-182. [CrossRef] [PubMed]

110. Effio, C.L.; Hubbuch, J. Next generation vaccines and vectors: Designing downstream processes for recombinant protein-based virus-like particles. Biotechnol. J. 2015, 10, 715-727. [CrossRef] [PubMed]

111. Astronomo, R.D.; Burton, D.R. Carbohydrate vaccines: Developing sweet solutions to sticky situations? Nat. Rev. Drug Discov. 2010, 9, 308-324. [CrossRef]

112. Yeh, M.T.; Bujaki, E.; Dolan, P.T.; Smith, M.; Wahid, R.; Konz, J.; Weiner, A.J.; Bandyopadhyay, A.S.; Van Damme, P.; De Coster, I.; et al. Engineering the Live-Attenuated Polio Vaccine to Prevent Reversion to Virulence. Cell Host Microbe 2020, 27, 736-751. [CrossRef]

113. Di Cristina, M.; Carruthers, V.B. New and emerging uses of CRISPR/Cas9 to genetically manipulate apicomplexan parasites. Parasitology 2018, 145, 1119-1126. [CrossRef] [PubMed]

114. King, A. Building a better malaria vaccine. Nature 2019, 575, S51-S54. [CrossRef]

115. Howe, D.K.; Sibley, L.D. Toxoplasma gondii Comprises Three Clonal Lineages: Correlation of Parasite Genotype with Human Disease. J. Infect. Dis. 1995, 172, 1561-1566. [CrossRef] [PubMed]

116. Innes, E.A.; Hamilton, C.; Garcia, J.L.; Chryssafidis, A.; Smith, D. A one health approach to vaccines against Toxoplasma gondii. Food Waterborne Parasitol. 2019, 15, e00053. [CrossRef] [PubMed]

117. Elbez-Rubinstein, A.; Ajzenberg, D.; Dardé, M.; Cohen, R.; Dumètre, A.; Yera, H.; Gondon, E.; Janaud, J.; Thulliez, P. Congenital Toxoplasmosis and Reinfection during Pregnancy: Case Report, Strain Characterization, Experimental Model of Reinfection, and Review. J. Infect. Dis. 2009, 199, 280-285. [CrossRef] 